\title{
Review of the book Sekurytyzacja jako narzędzie polityki zagranicznej Izraela $w$ świetle teorii regionalnych kompleksów bezpieczeństwa [Securitization as a tool of foreign policy of Israel in light of regional security complexes theory]. Author: Marcin Szydzisz
}

\section{Publisher: Wydawnictwa Uniwersytetu Warszawskiego. Warsaw 2018 [pp. 272]. ISBN 878-83-235-3767-0}

\section{Oleksandr Veretilnyk ${ }^{1}$}

The book consists of an introduction, five parts, conclusions, an abstract in English, a bibliography, a list of abbreviations and a personal index.

In the introduction, the author writes why he is interested in Israel's security problems, and also forms research questions and research hypotheses.

Part I Theoretical aspects and considerations consists of five subsections (parts). In this part, the author writes about what The Theory of Regional Security Complexes is, what the securitization policy is and what place it occupies in the foreign policy of states, and also writes about Israel's place in the Middle East and the internal

1 PhD student Doctoral School of the University of Szczecin Institute of Political Science and Security Studies, oleksandr.veretilnyk@ phd.usz.edu.pl. ORCID ID: 0000-0001-52864466. political aspects that affect Israel's foreign policy. In subsection 5 Internal factors affecting Israel's foreign policy, the author writes about the political system of Israel, about the role of the Prime Minister and the Minister of Foreign Affairs in the selection of objects for securitization (Szydzisz 2019, p. 31-34). In this subsection, the author also analyzes the political views of the main political parties in Israel: the Party of Labor, Likud and Kadima (Szydzisz 2019, p. 33).

Part II Global dimension of RKB consists of four subsections (parts). In this part, the author writes about Israel's relations with the United States, the United Nations, Russia, as well as the securitization of international terrorism. In subsection 3.1 Securitization of Russia, the author raises the issue of the participation of the Russian Federation in the Syrian war on the side of Israel's enemy - the regime of 
Bashar al-Assad. Russia supports not only Syria, but also Iran, but this, as the author writes, does not make it an enemy state for Israel. Israel does not see Moscow's policy in the Middle East as a threat to its security because it is not directed against Tel Aviv's interests (Szydzisz 2019, p. 96).

Part III The interregional dimension consists of three subsections (parts). In this part, the author writes about Israel's relations with NATO and the European Union. This is the smallest part of the bok.

Part IV The regional dimension consists of two subsections (parts). The first consists of 5 subsections. The second consists of 6 subsections. In this part of the book, the author writes about the challenges to regional security, about the influence of Egypt and Iran on the situation in the zone of the Arab-Israeli conflict (Szydzisz 2019, p. 136-158). The author pays special attention to the policies of the governments of Rabin, Barak, Sharon, Olmert and Netanyahu. Also in this part of the book, the author describes methods of securitization of threats posed to Israel's security by the Lebanese Shiite movement Hezbollah (which supports Iran), Lebanon, Jordan and Turkey (Szydzisz 2019, p. 159-174).

Part V Internal dimension consists of five subsections (parts). In this part of the book, the author writes about the evolution of Israeli policy towards the Palestinians, as well as about the armed Palestinian resistance to the Israeli occupation and the activity of the Hamas movement.
The topic of the book is relevant for political and security sciences because the Middle East remains in the center of attention of the international community, and relations between Israel and the Arab countries are beginning to change, as an example of the conclusion of a peace agreement between Israel and the United Arab Emirates ${ }^{2}$. All parts of the book are logically combined.

The author's research covers the period from 1993 to 2018 (Szydzisz 2019, p. 12). The style of writing the book is more journalistic than scientific. It has more historical description of events than scientific analysis.

This book, according to the reviewer, presents a pro-Israel perspective on events in the Middle East. The struggle of the Palestinian people for the de-occupation of their country is presented by the author as "Palestinian terrorism" (Szydzisz 2019, p. 226). The author even classifies as "radical" the Palestinian political groups participating in the democratic process in the Palestinian territories (Szydzisz 2019, p. 31). This contradicts the principle of neutrality accepted in the scientific community and can form the reader's wrong

${ }^{2}$ Neri Zilber, Normalization Deal Between Israel and the UAE Signals a Shift in the Region, https://foreignpolicy.com/2020/08/13/ israel-uae-normalization-west-bank-annexation/ [access: 23.08.2020] 
opinion about the real reasons for the Arab-Israeli conflict.

In the subsection Israel's place in the Middle East region, the author uses unconfirmed information about the policy of the Islamic Republic of Iran and claims that Tehran is trying to obtain nuclear weapons, which, according to the author, threatens Israel's security (Szydzisz 2019, p. 31, p. 146). It should be noted that the International Atomic Energy Agency (IAEA) has never confirmed Israel's accusations against Iran ${ }^{3}$.

The reasons for the conflict between Israel and Lebanon are not fully understood by the author. Describing the crisis in relations between Lebanon and Israel, as well as between Israel and the Lebanese movement Hezbollah, the author paid little attention to the fact that it is based on Israel's occupation of a part of Lebanese territory - the Shebaa Farms located in the occupied Golan Heights (Szydzisz 2019, p. 171). The occupation of Shebaa Farms and all of the Golan Heights determines the policy of Lebanon, Hezbollah and Syria towards Israel.

During the period that the author is researching (from 1993 to 2018), Israel also actively securitized Sudan and other Muslim countries in Africa. Israel considered Sudan an enemy state and actively

3 IAEA Reports. Downloaded from: https:// www.iaea.org/newscenter/focus/iran/iaeaand-iran-iaea-reports supported the separatists in South Sudan. In 2011, Israel became one of the first countries in the world to recognize the independence of the Republic of South Sudan. In 2012, the Israeli Air Force bombed Sudanese territory ${ }^{4}$. Tel Aviv claimed that Sudan exported weapons to Palestinian rebels. The securitization of Sudan was important to Israel, but the author does not write about it.

This book contains interesting material on the history of Israel, the history of armed conflicts in the Middle East with the participation of this state, but it should not be used as a didactic textbook for students who study international relations, diplomacy, etc. When reading Securitization as a tool of Israeli foreign policy in the light of the theory of regional security complexes, students may think that breaking international law and dehumanization can be justified if states do it for their own national security. In fact, international law is binding on everyone: for strong states as well as for weak ones. Nothing can justify the occupation of foreign territories, annexation, and the violation of human rights.

${ }^{4}$ Sudan blames Israel for Khartoum arms factory blast. Downloaded from: https://www. bbc.com/news/world-africa-20050781 